\title{
correspondence
}

\section{Incubator contamination}

Sir,- Tissue cultures usually require a $\mathrm{CO}_{2}$-in-air incubator to maintain the proper $p \mathrm{H}$ in the medium. When chemicals are introduced into the culture to test for their carcinogenic or mutagenic activity, potentially hazardous materials might be volatilised and released through the incubator vent.

Air from an incubator $\left(37^{\circ} \mathrm{C}\right)$ containing four large covered dishes, each of which held three smaller covered dishes containing about $50 \mu \mathrm{g}$ of safrole in $8 \mathrm{ml}$ of medium, was drawn through a bed of activated charcoal. The charcoal was treated with $\mathrm{CS}_{2}$, and the eluate was analysed by gas chromatography. The concentration of safrole in the gases vented from the incubator was about $2 \times 10^{-2}$ parts per $10^{\circ}$.

Concentrations of such magnitude may prove to be insignificant, but investigators should be aware of this possible source of contamination. A partial solution to potential exposure of personnel may be achieved by connecting the incubator vent to an exhaust system (for example, an operating chemical fume hood) by largebore tubing. This expedient will, however, neither prevent the release of potentially contaminated air into the laboratory each time the incubator is opened, nor eliminate the possibility of transmission of volatilised material from one dish to another within the incubator.

ERIC B. SANSONE

Frederick Cancer Research Center,

Frederick, Maryland 21701

\section{Angling right}

Sir,-Kenneth Mellanby (March 4, page 7 ) is right to claim that anglers are responsible for the continued existence of the large quantity and good quality of freshwater fish in parts of the United Kingdom, particularly in England where the need to pollute is greatest.

In earlier and cleaner times, when fish were threatened by over-harvesting, 74 Angling Societies in London were the principal supporters of the Mundella Bill for the Preservation of Nonmigrating Fish in England and Wales. It became law in 1878 (though not before jealous rows between the larger of the Societies and after fierce debates on whether or not to include a close season for the migrating species), and for the first time curbed the netting and marketing of "white fish", which by that time had reached wholesale proportions in the effort to feed fresh protein to a growing population.

Once refrigeration, Argentine beef and New Zealand lamb became available the pressure on freshwater food eased dramatically, and it is rare to meet anyone in this country who enjoys aromatically baked pike, grilled perch or the carp, once the favourite of the abbots. All three species are the equal of the salmon and infinitely superior to the pathetic offal-fed restaurant trout.

Today, as Mellanby emphasises, the danger is pollution in all its many and sometimes subtle guises, and it is curious how long it was before anglers organised themselves in a co-operative to spread the risk of the cost of bringing a Common Law action against interference of any kind with an established fishery. John Eastwood founded the Anglers Cooperative Association in 1948, and it has since won costs and compensation in almost a thousand cases of pollution, losing one on a technicality.

\section{H. I. S. Thirlaway}

Newbury,

Berkshire, UK

\section{Science indicators}

SIR,--It is often asserted that science ranks with politics at the bottom end of public esteem. But the survey conducted for the National Science Foundation in the US (March 18, page 184) discerned a remarkably favourable attitude toward science and technology among Americans. The survey found that $75 \%$ of the American public believes that science and technology have changed life for the better; a similar survey conducted in 1972 discovered that only $70 \%$ then held that belief. In addition, scientists and engineers were ranked second and third respectively in terms of occupational prestigebelow doctors, but above ministers of religion. Businessmen ranked lowest.

As for the impact of science and technology, there seems to be a certain amount of ambivalence. Some $57 \%$ of the respondents said they think that science and technology have done more good than harm, while $31 \%$ said they believe the beneficial and harmful impacts are evenly balanced. Only $2 \%$ believe that science and technology have done more harm than good. By far the most frequently cited benefit was improvements in medical care.

When asked whether social control over science and technology should be increased, $28 \%$ of the respondents replied that it should, while $46 \%$ said they believe the degree of control is about right.

The results of the survey also conflict sharply with the popular belief that young people are particularly turned off by science and technology -the attitudes of people under thirty differed little from those of elders.

Joseph SEILER

\section{Princeton,}

New Jersey 08540

\section{Mass and weight}

SIR, - The introduction of the SI system of units presented a great opportunity to clarify the difference between the concepts of mass and weight. It is thus disappointing that the use of the word kilogram has already in common parlance become associated with weight rather than mass. This is illustrated in the jingle put out by the British Metrication Board which you quote in an example in Competition 6 (March 18, page 188).

Although in most cases weighing is merely a convenient way of determining mass and "weights" used with balance-type instruments are calibrated in mass units, it would have been preferable, for example, to express the contents of a jar of jam as net mass $453 \mathrm{~g}$ rather than net weight, as has become the custom. The widespread television coverage of space flights has well illustrated the concept of weightlessness and it should no longer be difficult even for children to appreciate the distinction between mass and weight.

\section{Department of Geodesy and \\ J. A. J ACOBS \\ Geophysics, \\ Cambridge, UK}

\section{The JPU in modern science}

SIR,-D. Fraser is to be congratulated for his valuable concept of the JPU (Just Publishable Unit) presented in Nature (Correspondence, March 11). A more conservative measurement, however, is the JXPU (Just Xeroxable Published Unit), which may be defined as the smallest amount of published information normally considered worthy of xeroxing. An example being D. Fraser's correspondence.

Charles G. Waugh

University of Maine at Augusta,

Augusta, Maine 04330 